\title{
41AG9 and 41AG10: Ancestral Caddo Sites on Percella Creek in the Angelina River Basin in East Texas
}

Timothy K. Perttula

Heritage Research Center, Stephen F. Austin State University

Follow this and additional works at: https://scholarworks.sfasu.edu/ita

Part of the American Material Culture Commons, Archaeological Anthropology Commons, Environmental Studies Commons, Other American Studies Commons, Other Arts and Humanities Commons, Other History of Art, Architecture, and Archaeology Commons, and the United States History Commons

Tell us how this article helped you.

This Article is brought to you for free and open access by the Center for Regional Heritage Research at SFA ScholarWorks. It has been accepted for inclusion in Index of Texas Archaeology: Open Access Gray Literature from the Lone Star State by an authorized editor of SFA ScholarWorks. For more information, please contact cdsscholarworks@sfasu.edu. 


\section{AG9 and 41AG10: Ancestral Caddo Sites on Percella Creek in the Angelina River Basin in East Texas}

\section{Creative Commons License}

\section{(c) (1) \&}

This work is licensed under a Creative Commons Attribution-NonCommercial 4.0 International License 


\title{
41AG9 and 41Ag10: Ancestral Caddo Sites on Percella Creek in the Angelina River Basin in East Texas
}

\author{
Timothy K. Perttula
}

\section{Introduction and Setting}

Both 41AG9 (ET-609) and 41AG10 (ET-610) were identified and recorded by Gus E. Arnold in late 1939-early 1940 under the auspices of the very successful WPA University of Texas archaeological survey of East Texas; they are only ca. $400 \mathrm{~m}$ apart. The sites are on elevated alluvial landforms in the Percella Creek valley; Percella Creek is an eastward-flowing tributary to the Angelina River, and joins the river about $3 \mathrm{~km}$ to the east of the sites (Figure 1).

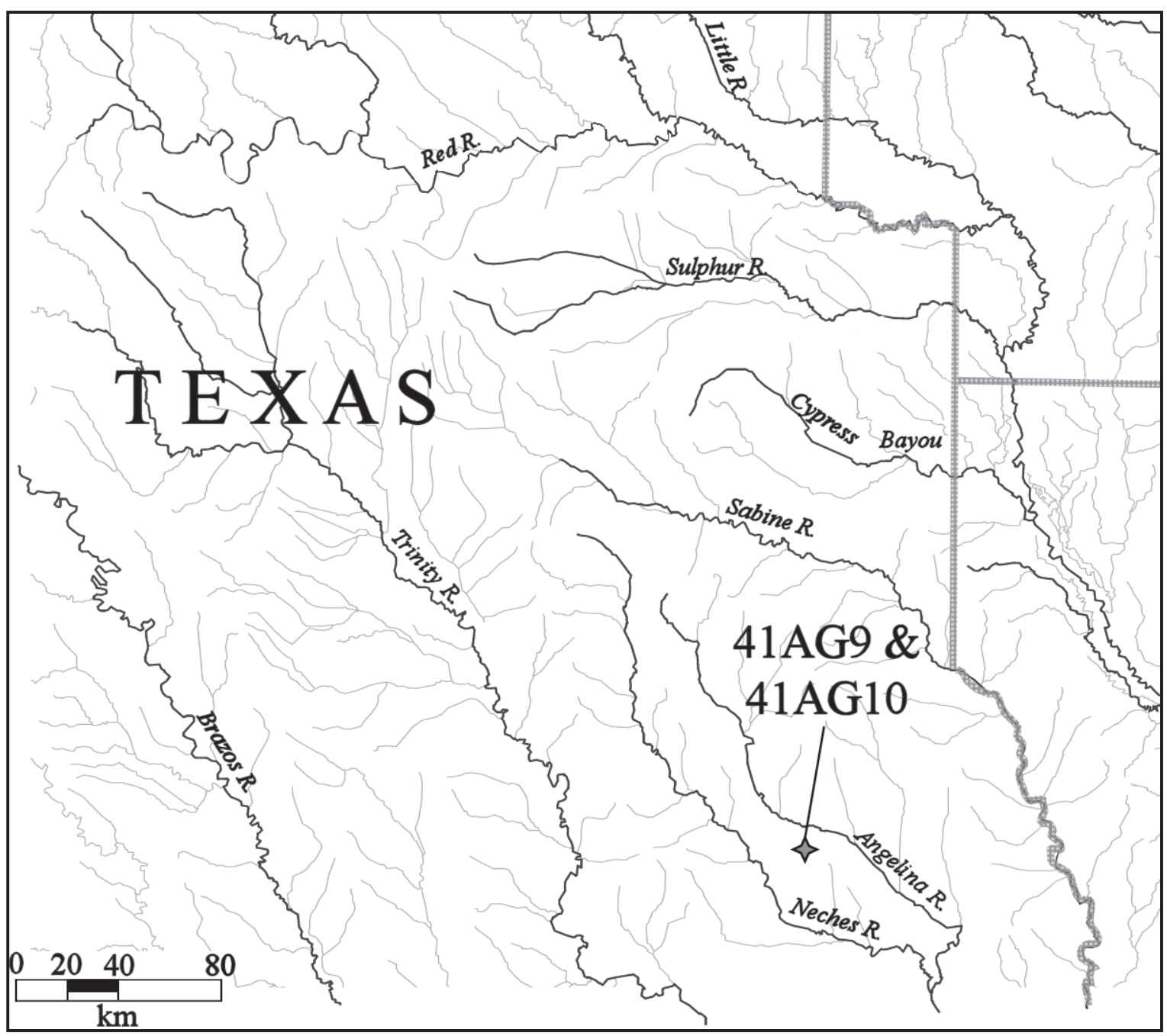

Figure 1. Location of 41AG9 and 41AG10 in East Texas. 
During Arnold's archaeological survey, he collected substantial numbers of ceramic vessel sherds from both sites, and the sites were in plowed fields with good surface visibility. 41AG9 was estimated to cover ca. 1.5 acres, and had midden deposits, as well as disturbed remnants of Caddo burial features. Midden deposits and remnants of possible disturbed Caddo burial features were also noted at 41AG10, and the core of the site covered a ca. $60 \times 60 \mathrm{~m}$ area (ca. 0.9 acres).

\section{AG9 Ceramic Sherd Assemblage}

There are 161 ceramic vessel sherds in the 41AG9 assemblage at the Texas Archeological Research Laboratory at The University of Texas at Austin (TARL). Two body sherds of Goose Creek Plain, var. unspecified are from a Woodland period use of the site (see Story 1990; Ellis 2013), while the remainder of the vessel sherds are the product of an ancestral Caddo occupation. The Caddo ceramic sherds are from either grog-tempered (83.6 percent) or bone-tempered (16.4 percent) vessels (Table 1)

Table 1. Caddo ceramic wares at 41AG9.

\begin{tabular}{lccc}
\hline Ware & Grog-tempered & Bone-tempered & N \\
\hline Plain & 41 & 4 & 45 \\
Utility & 91 & 21 & 112 \\
Fine & 1 & 1 & 2 \\
\hline Totals & 133 & 26 & 159 \\
\hline
\end{tabular}

In the ancestral Caddo ceramic assemblage as a whole, the plain to decorated sherd ratio is a low 0.39 . More than 98 percent of the decorated sherds are from utility ware vessels, particularly vessels with brushing decorative elements (Table 2). Brushed, brushed-incised-punctated (Figure 2b), and brushedpunctated (Figure 2a) sherds from Bullard Brushed vessels comprise 75.4 percent of the assemblage's decorated sherds; the brushed-incised-punctated sherd (Figure $2 \mathrm{~b}$ ) has a brushed rim and body, while the rim has incised triangle elements seen on Maydelle Incised vessels that are filled with tool punctations. The brushed to plain sherd ratio of the 41AG9 assemblage is 1.91, and the brushed to other wet paste sherds ratio is 2.61 .

Table 2. Decorative methods and elements in the utility ware and fine ware ceramic sherds from 41AG9.

Decorative methods and

$\operatorname{Rim}$ Body $\mathrm{N}$ decorative elements

\section{Utility Ware}

\section{Brushed}

horizontal brushed

opposed brushed

overlapping brushed

parallel brushed

$\begin{array}{lll}1 & - & 1 \\ - & 3 & 3 \\ - & 2 & 2 \\ - & 73 & 73\end{array}$

\section{Brushed-Incised-Punctated}

horizontal brushed rim with diagonal opposed 
Table 2. Decorative methods and elements in the utility ware and fine ware ceramic sherds from 41AG9, cont.

\begin{tabular}{llll}
\hline $\begin{array}{c}\text { Decorative methods and } \\
\text { decorative elements }\end{array}$ & Rim & Body & N
\end{tabular}

\section{Brushed-Punctated}

horizontal brushed and tool punctated row at lip opposed brushed and adjacent row of tool punctates parallel brushed and large circular punctations through the brushing parallel brushed and fingernail punctated row through the brushing parallel brushed and tool punctated rows through the brushing

\section{Incised}

cross-hatched incised lines curvilinear incised line diagonal incised lines parallel incised lines straight incised line

$\begin{array}{lll}1 & - & 1 \\ - & 1 & 1 \\ - & 1 & 1 \\ - & 1 & 1 \\ - & 2 & 2\end{array}$

Incised-Punctated

horizontal incised line below tool punctated rows incised triangle el. filled with tool punctated rows straight incised line and adjacent tool punctated row

$\begin{array}{lll}- & 2 & 2 \\ - & 1 & 1 \\ 1 & - & 1 \\ - & 9 & 9 \\ - & 2 & 2\end{array}$

\section{Punctated}

fingernail punctated rows

tool punctated rows

$\begin{array}{lll}- & 1 & 1 \\ 1 & - & 1 \\ - & 1 & 1 \\ & & \\ - & 2 & 2 \\ - & 6 & 6\end{array}$

\section{Fine Ware}

\section{Engraved}

parallel engraved lines and narrow hatched zone

\section{Slipped}

int./ext. red-slipped

$-\quad 1$

1

Totals

4

110

114

Other utility ware sherds include simple geometric incised elements (13.2 percent of the decorated sherds) from Maydelle Incised vessels; incised-punctated elements (2.6 percent) from Maydelle Incised vessels; and jars with rows of either fingernail or tool punctations (7.0 percent) on the rim and/or the vessel body. 


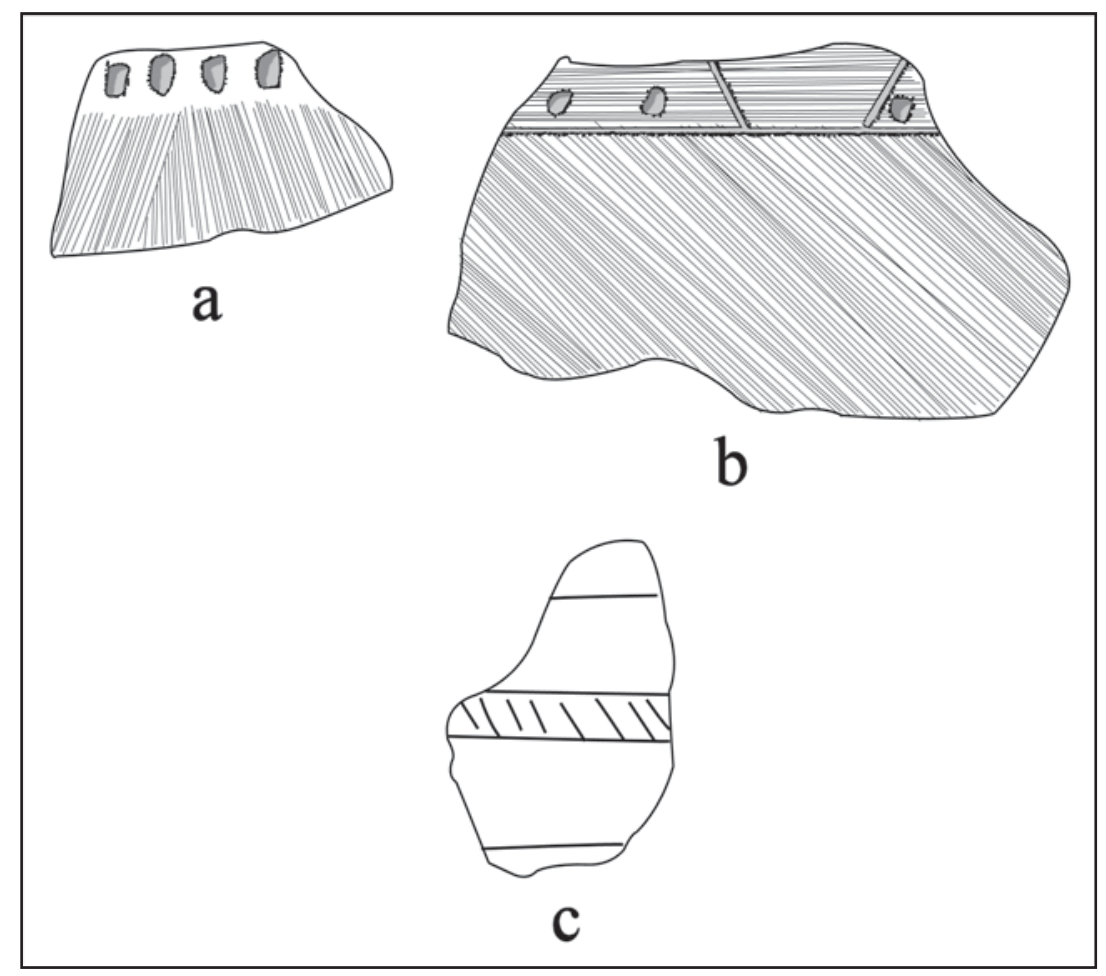

Figure 2. Selected decorated sherds from 41AG9: a, brushed-punctated; b, brushed-incised-punctated; $\mathrm{c}$, engraved.

One of the fine ware sherds has a red slip on both interior and exterior surfaces (see Table 2). The other is a bone-tempered body sherd with widely-spaced parallel engraved lines with a narrow hatched zone between the parallel lines (see Figure 2c).

\section{AG10 Ceramic Sherd Assemblage}

There are 155 ceramic vessel sherds in the 41AG10 assemblage at the Texas Archeological Research Laboratory at The University of Texas at Austin (TARL). As with 41AG9, two body sherds of Goose Creek Plain, var. unspecified are from a Woodland period use of the site (see Story 1990; Ellis 2013), while the remainder of the vessel sherds are the product of what appears to be a single ancestral Caddo occupation (Table 3). About 75 percent of the sherds are from grog-tempered vessels, and the remainder are from bone-tempered vessels; approximately 27 percent of the utility wares are from bone-tempered vessels.

Table 3. Caddo ceramic wares at 41AG10.

\begin{tabular}{lccc}
\hline Ware & Grog-tempered & Bone-tempered & N \\
\hline Plain & 26 & 6 & 32 \\
Utility & 84 & 31 & 115 \\
Fine & 5 & 1 & 6 \\
\hline Totals & 115 & 38 & 153 \\
\hline
\end{tabular}


The plain to decorated sherd ratio in this assemblage is 0.26 . This assemblage has a very high proportion of sherds (90.1 percent) from brushed and brushed-incised (Figure 3a) Bullard Brushed and Spradley Brushed-Incised vessels, reflected by a brushed to plain sherd ratio of 3.41 and a brushed to other wet paste sherds ratio of 12.1. Only 4.9 percent of the decorated sherds are from engraved fine ware vessels (Table 4).

Table 4. Decorative methods and elements in the utility ware and fine ware ceramic sherds from 41AG10.

\begin{tabular}{cccc}
$\begin{array}{c}\text { Decorative methods and } \\
\text { decorative elements }\end{array}$ & Rim & Body & N \\
\hline
\end{tabular}

\section{Utility Ware}

\section{Brushed}

diagonal brushed

horizontal brushed

opposed brushed

overlapping brushed

parallel brushed

$\begin{array}{lll}1 & - & 1 \\ 1 & - & 1 \\ - & 5 & 5 \\ - & 2 & 2 \\ - & 97 & 97\end{array}$

\section{Brushed-Incised}

horizontal and diagonal incised lines above diagonal

$\begin{array}{lll}- & 1 & 1 \\ - & 1 & 1 \\ - & 1 & 1 \\ - & & \\ - & 1 & 1 \\ - & 1 & 1\end{array}$

Incised

diagonal opposed incised lines

parallel incised lines

straight incised line

1

1

5

2

97

1

1

1

Punctated

large circular punctated rows

tool punctated rows

$1-2$

$\begin{array}{cll}- & 1 & 1\end{array}$

\section{Fine Ware}

\section{Engraved}

curvilinear engraved line/lines with excised tick marks diagonal and curvilinear opposed engraved lines horizontal engraved lines with excised tick marks oval-shaped excised tick mark below lip parallel engraved lines

\begin{tabular}{lll}
- & 2 & 2 \\
- & 1 & 1 \\
1 & - & 1 \\
1 & - & 1 \\
- & 1 & 1 \\
\hline 5 & 116 & 121 \\
\hline
\end{tabular}

Totals 


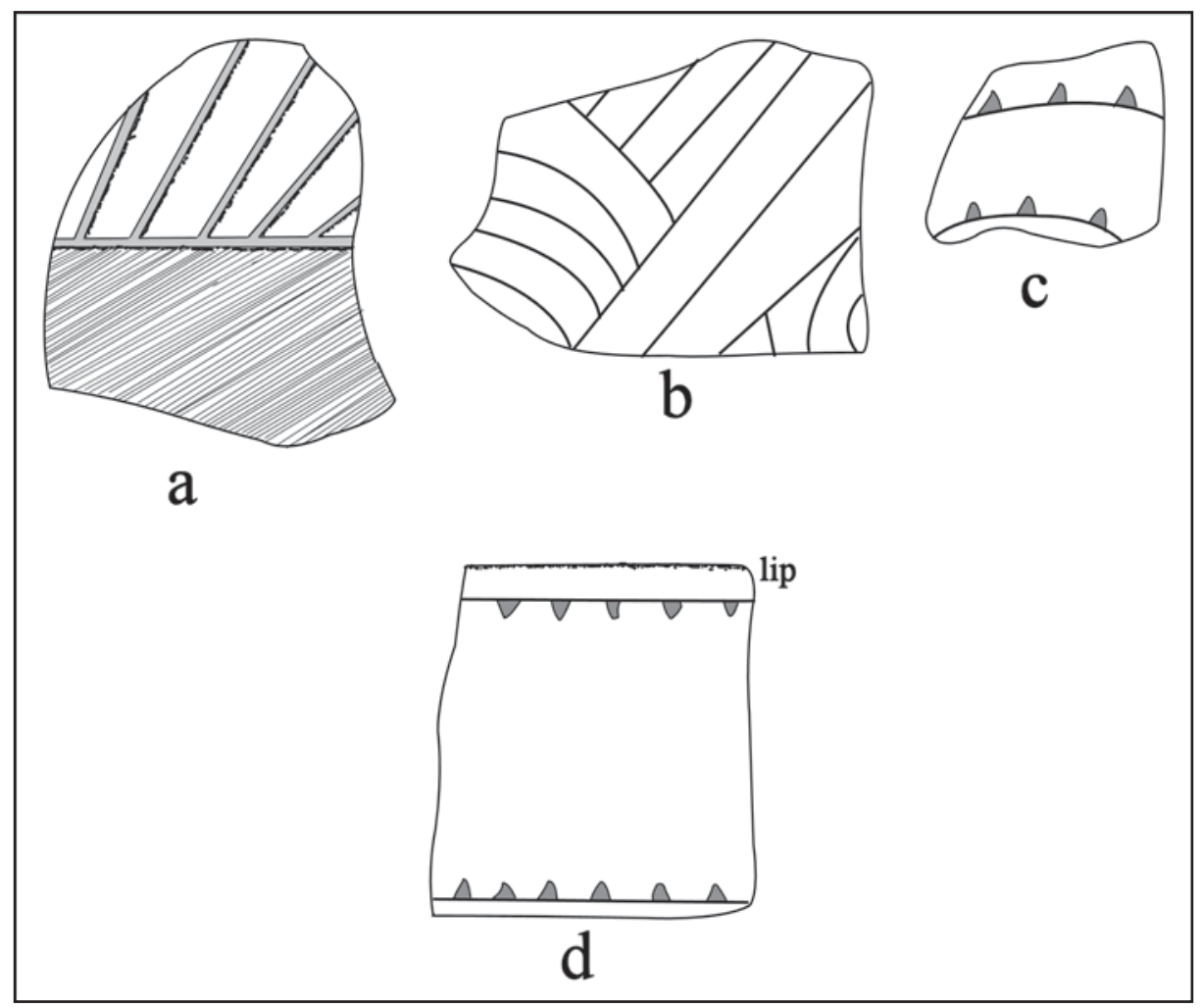

Figure 3. Selected decorative elements on utility ware and fine ware sherds in the 41AG10 assemblage.

The other utility wares in the $41 \mathrm{AG} 10$ ceramic assemblage include a few (2.5 percent of the decorated sherds) Maydelle Incised body sherds and rim and body sherds from vessels decorated with rows of either large circular or tool punctations (2.5 percent) (see Table 4).

Four of the fine ware sherds from 41AG10 are from Patton Engraved, var. Fair vessels (see Figure 3c-d; see also Perttula 2011:Figure 6-66d), with distinctive excised tick marks on rim and body elements (see Table 4). Another engraved sherd, from a bottle, has sets of diagonal and curvilinear engraved lines on the vessel body (see Figure $3 b$ ).

\section{Summary and Conclusions}

Sites 41AG9 and 41AG10 are ancestral Caddo sites in the Angelina River basin in East Texas. They were first identified and documented by Gus Arnold in late 1939-early 1940, and he obtained substantial samples of ceramic vessel sherds from both sites. The collections both contain a few Woodland period Goose Creek Plain, var. unspecified sherds, but the vast majority of the plain and decorated sherds -153 to 159 sherds per site - are from Caddo occupations that date after ca. A.D. 1650 or even after ca. A.D. 1680. The ceramic assemblages are primarily comprised of sherds from grog-tempered vessels, particularly vessels decorated with brushing marks on rim and body surfaces (75.4-90.1 percent of all the decorated sherds), and fine ware sherds are rare in both assemblages. The occurrence of sherds from Patton Engraved and Spradley Brushed-Incised vessels indicate that 41AG10 was occupied during the post-A.D. 1680 Historic Allen phase by an Hasinai Caddo community, while 41 AG9 may be a generation or two older in age. Nevertheless, the stylistic and functional character of the ceramic assemblages at the two nearby sites suggests they are part of the temporal trajectory of Caddo settlements and communities in this part of the Angelina River basin. 
The closest comparison between the ceramic assemblages at 41AG9 and 41AG10 and other East Texas Historic Caddo assemblages lies with Area II and Area VI Historic Caddo sites in the Neches and Angelina River basins (Table 5 and Figure 4)

Table 5. Comparisons between East Texas Historic Caddo assemblages.

\begin{tabular}{llll}
\hline Areas & $\begin{array}{l}\text { Percent Brushed in } \\
\text { Decorated Sherds }\end{array}$ & $\begin{array}{l}\text { Brushed/ } \\
\text { Wet Paste }\end{array}$ & Cluster \\
\hline I, Nadaco, Sabine River & 64.8 & 1.95 & Nadaco \\
& 90.8 & 11.38 & None Identified \\
II, lower Neches & $\mathbf{9 0 . 1}$ & $\mathbf{1 2 . 1}$ & \\
41AG10 & $\mathbf{7 5 . 4}$ & $\mathbf{2 . 6 1}$ & \\
41AG9 & $82.7-88.1$ & $8.14-9.63$ & Upper Neches \\
III, Upper Neches & 87.4 & 6.34 & Neche \\
III, Neche, I & & & \\
& 81.3 & 6.74 & Neche \\
IV, Neche, II & 71.4 & 4.36 & Nabedache \\
IV, Nabedache & 70.0 & & \\
& 66.8 & 2.30 & Legg Creek \\
V, Middle Angelina II & 84.7 & 3.08 & Nasoni \\
V, Nasoni/East Fork Angelina & 81.8 & 6.71 & King Creek \\
VI, Middle Angelina I & 60.9 & 8.89 & Bayou Loco South \\
VI, Bayou Loco I & 56.5 & 1.86 & Bayou Loco North \\
VII, Bayou Loco II & & 2.25 & Nacogdoche \\
VII, Bayou La Nana & 50.0 & 1.72 & Attoyac \\
VIII, Attoyac Bayou II & 30.4 & 0.61 & Upper/Lower Attoyac \\
VIII, Attoyac Bayou I & 0.0 & 0.0 & Ais \\
IX, Ais mission & & & \\
\hline & & & \\
\hline
\end{tabular}

The lower Neches area (Area II) ceramics have the highest proportion of brushed sherds in decorated sherd assemblages and the highest ratios of brushed to other wet paste sherds (see Table 4); 41AG10 has very similar ceramic metrics. But the sites in this area have not been specifically affiliated with an Hasinai Caddo group. Ceramic group VI represents one of the core areas of known Hasinai Caddo ceramic assemblages in the Angelina River basin (see Figure 4 and Table 5). Mid-Angelina River basin sites (King Creek) are stylistically similar to both Bayou Loco and Bayou La Nana assemblages (see Figure 4 and Table 5). These latter groups may be affiliated with both Hainai and Nacogdoche Caddo groups living in this part of East Texas throughout the $18^{\text {th }}$ century. The mouth of Bayou La Nana is less than $5 \mathrm{~km}$ from the two Angelina County sites discussed in this article that are on Percella Creek, and there may have been considerable social relationships between the peoples that lived at 41AG9 and 41 AG10 and the nearby Hainai and Nacogdoche Caddo. 


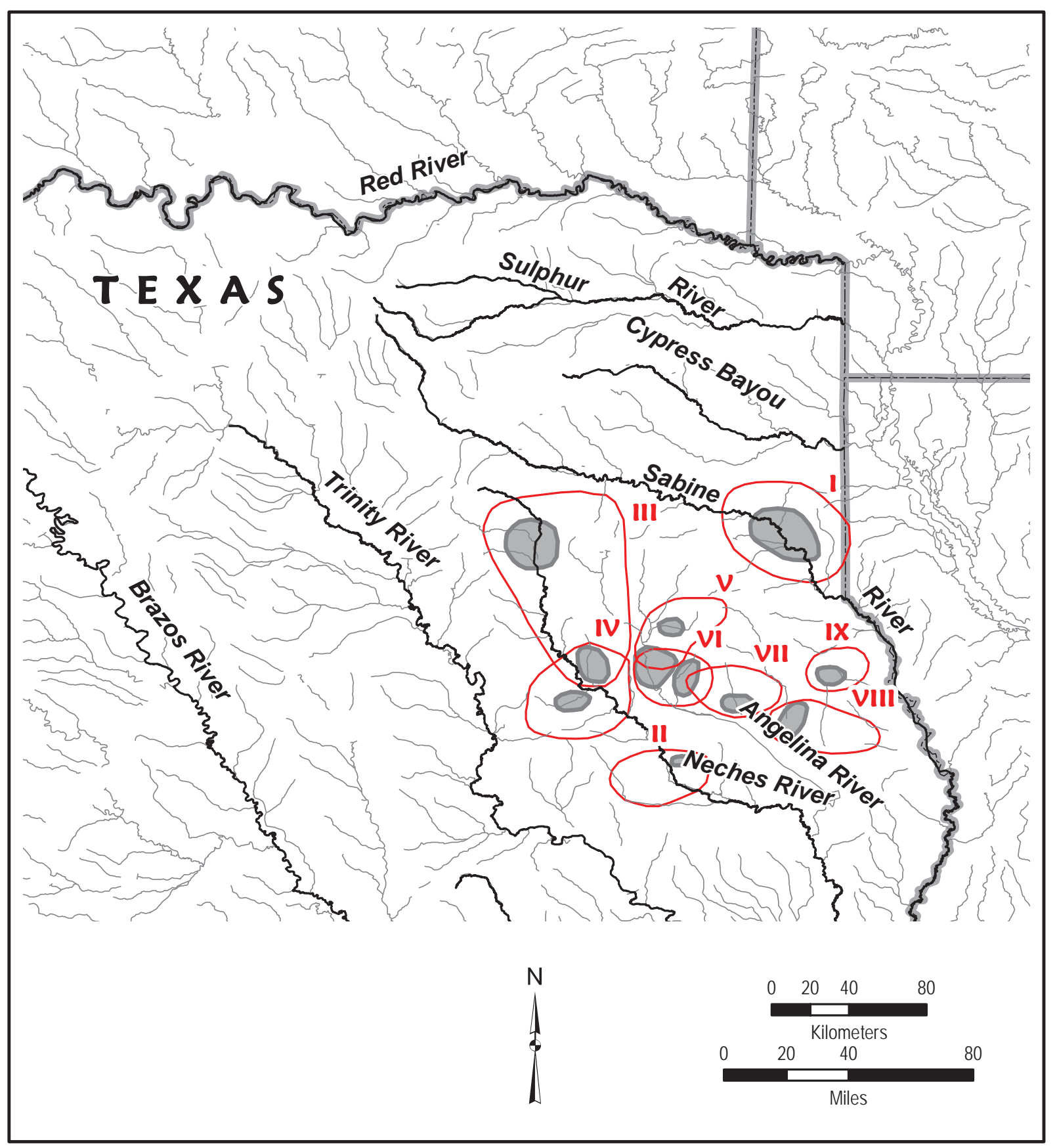

Figure 4. Historic Caddo Ceramic Areas in East Texas. 


\section{Acknowledgments}

I appreciate the efforts of Lauren Bussiere at TARL for her help in accessing the collections from 41AG9 and 41AG10. Lance Trask prepared Figures 1-3 for this article and Sandy Hannum prepared Figure 4.

\section{References Cited}

Ellis, L. W.

2013 Woodland Ceramics in East Texas and a Case Study of Mill Creek Culture Ceramics. Bulletin of the Texas Archeological Society 84:137-180.

Perttula, T. K.

2011 The Ceramic Artifacts from the Lang Pasture Site (41AN38) and the Place of the Site within an Upper Neches River Basin Caddo Ceramic Tradition. In Archeological Investigations at the Lang Pasture Site (41AN38) in the Upper Neches River Basin of East Texas, assembled and edited by T. K. Perttula, D. B. Kelley, and R. A. Ricklis, pp. 145-320. Archeological Studies Program Report No. 129, Texas Department of Transportation, Environmental Affairs Division, Austin.

Story, D. A.

1990 Cultural History of the Native Americans. In The Archeology and Bioarcheology of the Gulf Coastal Plain, by D. A. Story, J. A Guy, B. A. Burnett, M. D. Freeman, J. C. Rose, D. G. Steele, B. W. Olive, and K. J. Reinhard, pp. 163-366. Research Series No. 38. 2 Vols. Arkansas Archeological Survey, Fayetteville. 